\title{
Article
}

\section{Analysis and Evaluation of the Photovoltaic Market in Poland and the Baltic States}

\author{
Ewa Chomać-Pierzecka ${ }^{1, *(\mathbb{D}}$, Andrzej Kokiel ${ }^{2}$, Joanna Rogozińska-Mitrut ${ }^{1}$, Anna Sobczak ${ }^{1}{ }^{1}$, Dariusz Sobon ${ }^{1}$ \\ and Jacek Stasiak ${ }^{3}$
}

check for updates

Citation: Chomać-Pierzecka, E.; Kokiel, A.; Rogozińska-Mitrut, J.; Sobczak, A.; Soboń, D.; Stasiak, J. Analysis and Evaluation of the Photovoltaic Market in Poland and the Baltic States. Energies 2022, 15, 669. https://doi.org/10.3390/ en15020669

Academic Editor: Javier Contreras

Received: 15 December 2021

Accepted: 14 January 2022

Published: 17 January 2022

Publisher's Note: MDPI stays neutral with regard to jurisdictional claims in published maps and institutional affiliations.

Copyright: (C) 2022 by the authors. Licensee MDPI, Basel, Switzerland. This article is an open access article distributed under the terms and conditions of the Creative Commons Attribution (CC BY) license (https:// creativecommons.org/licenses/by/ $4.0 /)$.
1 Faculty of Economics, Jacob of Paradies Academy in Gorzów Wielkopolski, 66-400 Gorzów Wielkopolski, Poland; joanna_rogozinska@wp.pl (J.R.-M.); asobczak@ajp.edu.pl (A.S.); dsobon@ajp.edu.pl (D.S.)

2 Faculty of Economics, The WSB University in Poznan, 61-895 Poznan, Poland; andrzejkokiel@wp.pl

3 Non-Public Health Care Centre Interschool Department of Rehabilitation and Correction Science and Research Center, 95-070 Aleksandrów Łódzki, Poland; jacek_stasiak@interia.pl

* Correspondence: echomac-pierzecka@ajp.edu.pl

\begin{abstract}
The household, industrial, and service sectors in Poland and the Baltic States have been facing ever-higher bills for their electricity consumption at a time when a number of them have been hit hard financially by the pandemic. Rising inflation, the border crisis-with its set of restrictions, or the spread of the fourth wave of the COVID-19 coronavirus pandemic, is causing strong concerns in the social and economic sphere, with significant increases in electricity prices. Many countries are implementing measures to reduce the adverse effects of rising electricity prices in response to this complex situation. The main orientation is towards obtaining energy from renewable sources, such as the sun. The current situation in the energy market determines the price per $1 \mathrm{KW}$. Among the countries under study, the price of electricity has increased the most in Poland. On the other hand, the development of the photovoltaic segment in Poland is undergoing a strong, upward trend. The above inspired the authors to explore the energy market situation in Poland and the Baltic States in the current economic conditions, along with an analysis of its development potential in light of the coronavirus pandemic. The main research problem of this study is an attempt to answer the question of what should be changed in the development of the renewable energy market in Poland, with particular emphasis on photovoltaics, to accelerate the process of reducing $\mathrm{CO}_{2}$ emissions, leading to a reduction in dramatically rising electricity prices. Which solutions implemented in the Baltic countries can inspire strengthening Poland's energy market development?
\end{abstract}

Keywords: energy market; renewable energy; electricity prices; photovoltaics; renewable energy

\section{Introduction}

The household, industrial, and service sectors in Poland and the Baltic States have been facing ever-higher bills for their electricity consumption at a time when a number of them have been hit hard financially by the pandemic. Rising inflation, the border crisis-with its set of restrictions, or the spread of the fourth wave of the COVID-19 coronavirus pandemic, is causing solid concerns in the social and economic sphere, with significant increases in electricity prices. In response to this complex situation, several countries are implementing measures to reduce the negative effects of electricity price increases. In addition to actions in the regulatory sphere, affecting the price of electricity or the system of subsidies to the costs of its purchase, the system of actions related to the promotion of alternative formulas for obtaining electricity, oriented towards the modification of energy markets based on traditional sources (fossil fuels) to an energy economy based on renewable energy sources (wind energy, solar energy, geothermal energy, wave energy, current and tidal energy, energy from the fall of rivers, biomass energy) [1] is fundamental. This seems to be an 
absolute necessity [2], and the support in the field of eco-installations (especially in the financial sphere) is an important impulse for taking up the challenges in this area.

The authors concluded that renewable energy sources should be the basis for developing the energy market in the world. Although this is an obvious aspect related to the dimension of the modern energy economy, many differences can be observed in the progress of implementation of RES solutions and the types of undertaken solutions, reflected in the price of electricity per $1 \mathrm{kWh}$. Significant differences in this respect can be observed in the example of countries of the Baltic Sea basin, where Poland leads in the production of electricity from non-renewable sources (82\%) [3]. The context outlined above justifies the need to investigate the current situation of the energy market in Poland and in the Baltic countries as its stability directly translates into efficient functioning of entities in this area in the social [4] and economic [5] dimensions.

Having the above in mind, the general purpose of the paper is to examine the differences in the progress of the Baltic Sea countries in implementing solutions related to obtaining energy from renewable sources. The rationale for choosing the Baltic Sea countries is their direct vicinity and the similar general social and economic conditions of Poland and the Baltic countries, providing the basis for substantive comparisons.

The main objective of this study was to investigate the current situation of the energy market in Poland and the Baltic States, with a particular focus on photovoltaics as a direction for the development of alternative forms of electricity generation. This choice is supported by the fact that Poland, as the least advanced country in the field of renewable energy, has been recently leading the way in terms of photovoltaic development. The objectives of this paper are to diagnose the state of the electricity market in the current economic conditions, to present the essence of the photovoltaic process and to analyze the potential development of the photovoltaic market in Poland and the Baltic countries, as well as to assess the impact of the coronavirus pandemic COVID-19 on the development of the photovoltaic market in Poland and the Baltic countries. The main research problem of this study, however, is an attempt to answer the question of what can be changed in the development of the renewable energy market in Poland, with particular emphasis on photovoltaics, to accelerate the process of reducing $\mathrm{CO}_{2}$ emissions, leading to a reduction in dramatically rising electricity prices. Which of the solutions implemented in the Baltic countries can be an inspiration to strengthen the development of the energy market in Poland, based on renewable energy sources?

Similar studies have been conducted in different countries. It is worth pointing out that the literature on the subject provides numerous examples of studies of the energy market in the countries of the Baltic Sea basin, most often realized for the Baltic countries-Lithuania, Latvia, and Estonia [1], thus including Poland in analyses of this type will broaden their spectrum, limiting a kind of research gap. The above is justified by the current need for information on the energy market in the region, which is another reason for establishing a research area for this study. The selected countries are also characterized by a differentiated approach to the implementation of solutions allowing for obtaining energy from renewable sources, which is confirmed, among others, by the content of the Sustainable Development Report 2019: Transformations to Achieve the Sustainable Development Goals, according to which Estonia is in the lead, ranking 10th in the ranking of $193 \mathrm{UN}$ member states in terms of changes in indicators for the Sustainable Development Goals by 2030 (including the green energy index), followed by Latvia in 24th place, Poland in 29th place and Lithuania in 32nd place [6]. In addition, the selection of countries was based on the availability of analytical data in Eurostat and industry reports published, among others, on the Internet to ensure comparability of data and appropriate quality of research results.

The paper adopts the following structure: Section 1 contains the introduction, Section 2 contains the literature review on the development of the photovoltaic energy market in the world. Section 3 presents the results of the research on the analysis of the photovoltaic market in Poland and the Baltic States along with the assessment of its development trends, 
taking into account the impact of the coronavirus pandemic and the recommendations formulated based on the research results Section 4 contains the discussion and conclusions.

\section{Global Photovoltaic Market Development-Literature Review}

The efficiency of the energy market determines economic development. The professional literature provides numerous analyses in the field of the influence of energy factors on the growth of individual economies worldwide [7-10]. The above gains particular significance in the era of the coronavirus pandemic where, on the one hand, the reduction in the extraction of fossil fuels has contributed to a change in consumer behavior and an increase in demand for energy obtained from renewable sources [11], and, on the other hand, the support for the development of the renewable energy market takes place at the expense of supporting the fossil fuel extraction sectors in the countries dependent on this industry [12]. Actions promoting the acquisition of green energy-essentially limiting its cost-seem to be highly justified in the reality of the crisis caused by the pandemic. The above should be mainly considered in countries whose main energy production capacities are concentrated around non-renewable sources. The recently observed increases in energy prices in countries where energy is obtained traditionally (e.g., Poland) [13] deepen the general rise in prices, which may be the basis for social unrest [14].

The virtues of green energy are recognized by many countries, contributing to changes in energy acquisition policies [15,16]. Individual economies are opening up to Sustainable Development [6] and increasing energy efficiency. Awareness about the negative impact of the traditional energy sector on the environment is increasing, and its effects on climate change $[17,18]$ are increasingly raised. Therefore, caring for the environment and the search for alternatives to classical, nature-harming solutions in the sphere of energy acquisition and distribution have become more important than ever. "Green energy" convinces the world and is currently a desired trend in developing the global energy market. Maintaining high, in global terms, demand for electricity, with rising prices for $1 \mathrm{KW}$ of energy produced traditionally-correlated with the increasing level of environmental fees-justifies the above from an economic point of view. The above applies particularly strongly to Poland, which depends on traditional forms of energy generation $[19,20]$ and needs urgent changes in the energy sector, affecting technological, environmental, and economic aspects [21]. The opening to distributed energy from RES sources is marked in the Polish Energy Policy and its subsequent revisions [22,23].

The global RES market is growing, [12] especially the solar and wind energy sectors, and the coronavirus pandemic has not slowed down this development [19], which can be confirmed in the literature [24,25]. Strong development of the indicated sectors of the RES market empowered the authors in the choice of exploring, within the framework of this article, the thread of one of them-a technique-oriented to the conversion of energy obtained from solar radiation into electricity, based on the photovoltaic effect. What does it consist of?

The accumulation of solar energy (photon strands) into charge in a semiconductor takes place in a photovoltaic unit (cell), which builds the energy conversion module-the photovoltaic panel. The essence of the process arises from the construction of photovoltaic cells, which in most cases consist of a semiconductor in the form of silicon crystals (monocrystalline or polycrystalline), the irradiation of electrons building which, releases a higher energy level (electron-hole). The burst and movement of the electrons trigger a potential difference and the phenomenon of DC accumulation. At the same time, in the inverter, its conversion from alternating to direct current [26] is carried out. The photovoltaic process outlined above is based on the quality of the silicon crystals. Its type and structure determine the quality of the equipment for converting solar energy into electricity. The efficiency of the photovoltaic effect is therefore created on the technical side by the number of electrons and the number of bonds, which is combined with the quality of the solar energy, determined by the intensity and the length of the solar radiation resulting from the geographical location of the photovoltaic installation [27] (longitude and latitude, 
correlated with the time of the calendar year) and the correct choice and achievement of the optimal direction and degree of inclination of the photovoltaic installation at the place of solar energy intake (azimuth). Also important is the surface type under the PV modules [28]. The quality of the semiconductor used-its crystal structure, the type of cell bonding used, and the type of anti-reflective coatings applied-is therefore important in selecting a solution [24]. The quality of solar radiation, correlated with the conditions of its reception and conversion [29,30], determines the energy efficiency of a specific solution.

Renewable energy is on the rise in response to global demand. Solar energy is growing mainly in the sunnier parts of the world, but it is also becoming increasingly important in less sunny regions. For example, China achieved spectacular results in the photovoltaics field with a connection capacity in 2020 of $48.2 \mathrm{GW}$, and the USA has achieved 19.2 GW [31]. In addition, India and Saudi Arabia have achieved outstanding results in the photovoltaic sector [32].

Solar energy in the European Union has grown strongly over the past few years [33-35]. Hence, the photovoltaic sector is an important pillar of green energy in the European energy market [36]. The undisputed leader in the photovoltaic sector in the European market is Germany with a total connected capacity of more than $50 \mathrm{GW}$, followed by Italy ( $21 \mathrm{GW}$ ), the United Kingdom (13.3), while Poland in this ranking is in the second ten [37], ahead of the Baltic States.

The above literature review provides a background for further research-oriented towards analyzing the photovoltaic market in Poland and the Baltic States, in line with the objective presented in the introduction.

\section{Materials and Methods}

The research at the outset was conceptual in nature. However, the considerations undertaken in this article are analytical and empirical. The research was based on the analysis of industry reports on the energy market in Poland and the Baltic countries (Lithuania, Latvia, and Estonia), statistical studies communicated at the level of the countries adopted for the analysis, as well as relating to the European Union market in general, and on the results of own research on the development of the photovoltaic micro-installation segment in the energy market in Poland, in the topic of determinants of investment decisions, in connection with the purchase of photovoltaic solutions. Systematization and decomposition techniques and comparative and situational analysis methods were used. In addition, methods typical for planning and forecasting were used. Figure 1 presents the research algorithm.

The study was based on an extensive literature list. In addition, a content analysis of world literature on the photovoltaic energy market and industry reports on the latest trends in the development of the energy sector was carried out to show trends and new solutions applicable in the studied countries. Although the topic addressed in this paper is quite important and relevant, there are different models in the scientific and journalistic literature for the introduction of PV and its participation in the overall energy market. Furthermore, there are a limited number of national studies devoted to analyzing the prospects of the domestic photovoltaic industry from the perspective of the global energy transition. Therefore, the basis of the research is primarily foreign scientific articles, studies, and international reports, forecasts, predictive estimates, and statistical data.

The authors have tried to cover the main trends and issues related to the discussed topic and have consistently moved from the global experience to the Polish and Baltic experiences to answer the questions posed in the research. To gain insight into the Polish intentions related to energy transition trends, a critical analysis of the current situation has been carried out, and conclusions from final consumer behavior surveys and interviews conducted among representatives of companies active in the energy transition have been presented. 


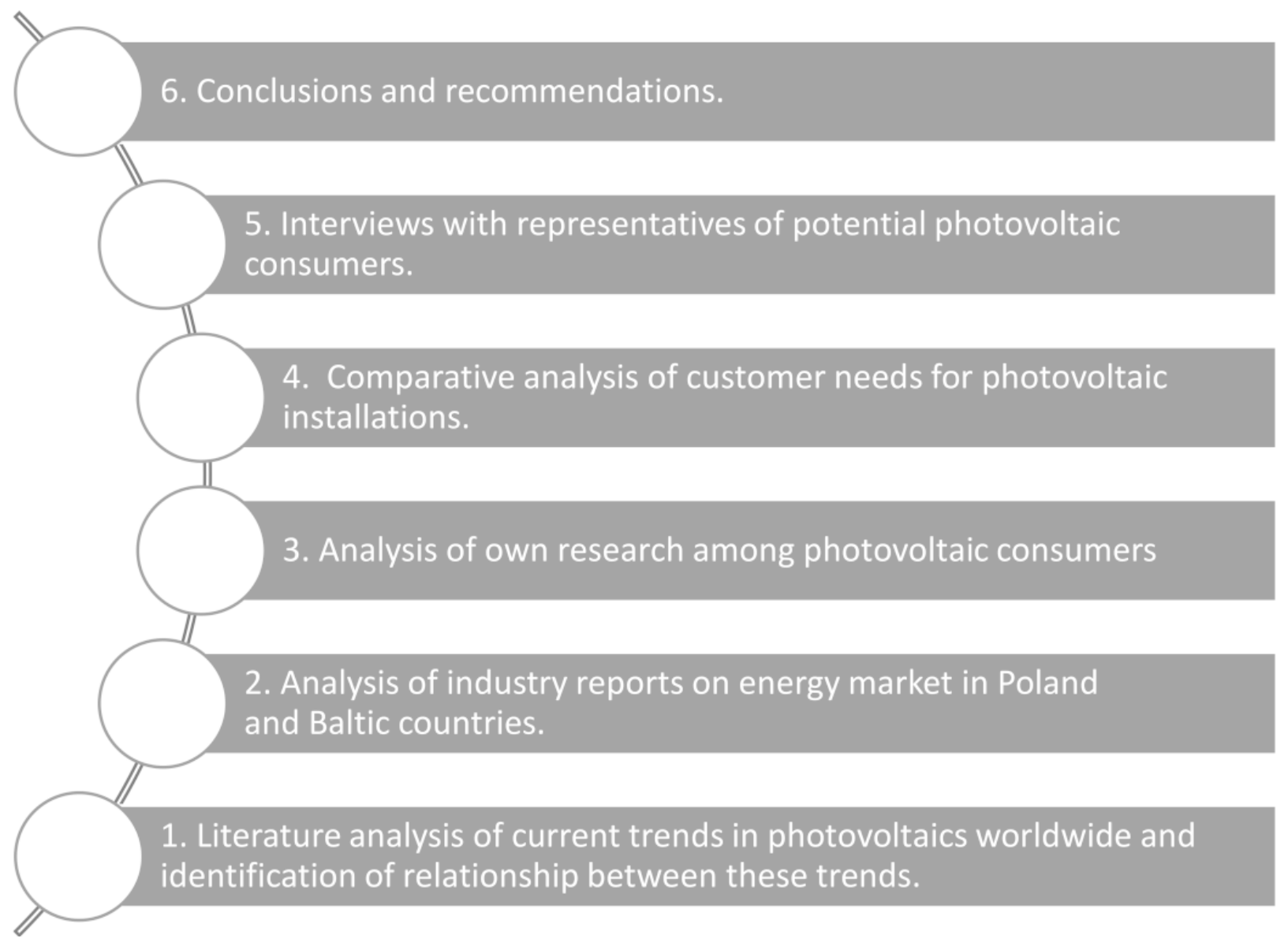

Figure 1. Research algorithm [38].

The authors intend to deepen their knowledge and collect results on the production of "green" technologies to develop a model that best fits the realities of the Polish and Baltic economies. In order to obtain a common vision of current plans and intentions and collect quantitative data from pro consumers, the authors have now extended the survey and conducted interviews to obtain reliable forecast estimates.

\section{Results}

\subsection{Diagnosis of the Energy Market Situation in Poland and the Baltic States}

The degree of advancement of efforts to reduce conventional electricity generation, correlated with the level of $\mathrm{CO}_{2}$ emissions [39] and regulatory processes regarding its permissible levels (with rising prices of carbon allowances), determines the price system per $1 \mathrm{KW}$. The above is also influenced by the situation of economies operating in pandemic realities and the increase in prices of energy raw materials; hence, the changes in electricity prices in Poland and the Baltic States (Lithuania, Latvia, and Estonia) are differentiated in terms of their degree and direction. The most significant price increase in the analyzed set of countries concerns the Polish energy market, with the increase in the period 2019-2020 also covering the Lithuanian energy market. Latvia saw an increase in prices per $1 \mathrm{KW}$ only in the current year, while electricity prices in Estonia are gradually decreasing, although already at a minimum level in the current period. (Table 1).

The level of average prices per $100 \mathrm{kWh}$ of electricity in the period 2019-2021 in Poland and the Baltic States, expressed in European currency, assumed the following values-Table 2 .

The varying pattern of electricity prices across European economies shapes the average price per $100 \mathrm{kWh}$ in the European Union, which remains relatively stable-Figure 2. 
Table 1. Average changes in electricity prices between 2019 and 2021 in Poland and the Baltic States, relative to national currencies [40].

The Average Change in Electricity Prices in Poland and the Baltic States in the Period 2019-2021 Relative to National Currencies

\begin{tabular}{cccc}
\hline & $\mathbf{2 0 1 9}$ & $\mathbf{2 0 2 0}$ & First Half of 2021 \\
\hline Poland & +9.7 & +14.1 & +8 \\
\hline Lithuania & +5 & +5.3 & -6 \\
\hline Latvia & -8 & -12.7 & +7 \\
\hline Estonia & -13 & -8.5 & -1 \\
\hline
\end{tabular}

Table 2. Changes in average electricity prices per 100 KWh in 2019-2021 in Poland and the Baltic States [40].

\begin{tabular}{|c|c|c|c|}
\hline \multicolumn{4}{|c|}{ Average Electricity Price during the Period 2019-2021/100 KWh, Expressed in Euro } \\
\hline & 2019 & 2020 & First Half of 2021 \\
\hline Poland & 13.76 & 15.1 & 15.48 \\
\hline Lithuania & 12.54 & 13.2 & 13.48 \\
\hline Latvia & 16.4 & 14.3 & 14.03 \\
\hline Estonia & 14.11 & 12.9 & 13.24 \\
\hline
\end{tabular}

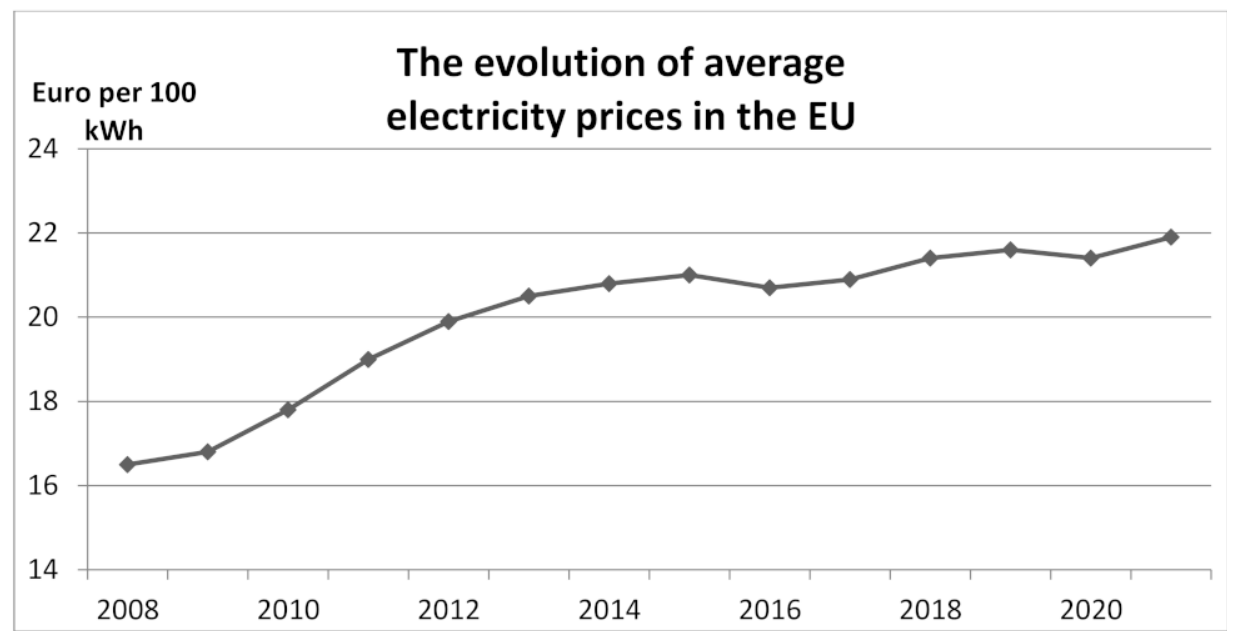

Figure 2. The evolution of average electricity prices per $100 \mathrm{KWh}$ between 2019 and 2021 in the European Union [41].

Against the background of the analyzed group of countries, Poland adopts the highest electricity price increases. This increase in electricity after 1 January 2020 was released by the expiry of the Act on electricity prices binding until the end of 2019, hence after 1 January 2020, there was a strong increase of almost $20 \%$, motivated by the current price of $\mathrm{CO}_{2}$ emission allowances, as well as an increase in generation costs and related prices for hard coal and lignite. Changes in prices are also shaped by the change in the value of the distribution fee, determined by the economic situation [42]. It is worth noting that the structure of distribution fees is shaped by as many as nine cost items, which include: the charge for commissioned power, subscription fee, cost of active energy, cost of distribution fixed, cost of the distribution variable, quality charge, transitional charge, renewable energy sources charge (RES), cogeneration levy.

The system of retail electricity prices of Poland in the period 2017-2021 increased significantly, and the average selling price of $1 \mathrm{kWh}$ adopted the following values: PLN 0.55 in 2017-2019, PLN 0.62 in 2020, and PLN 0.63 in 2021 (with the cost arrangement: 
PLN 0.38 per $1 \mathrm{kWh}$ plus PLN 0.25 per $1 \mathrm{kWh}$ for distribution charges). According to the announcement of the Energy Regulatory Office, further increases of both electricity purchase tariffs (as a rule G11 or G12) and the components of distribution fees are to be expected, wherein 2022, the fee for ordered power is to increase by approximately $21 \%$, and assumed price levels between PLN 2.37 and PLN 13.25 PLN [43] in the monthly settlement.

Electricity exchange prices in Poland in September 2021 reached a record level of 401 PLN per MWh (historically 120 EUR), achieving a $68 \%$ increase compared to August. However, compared to the Baltic States, it is a relatively good result. For example, the level of exchange prices in the corresponding period in Lithuania and Latvia amounted to 143 Euro per 1 MWh, while in Estonia it was 142 Euro per 1 MWh [44]—Figure 3.

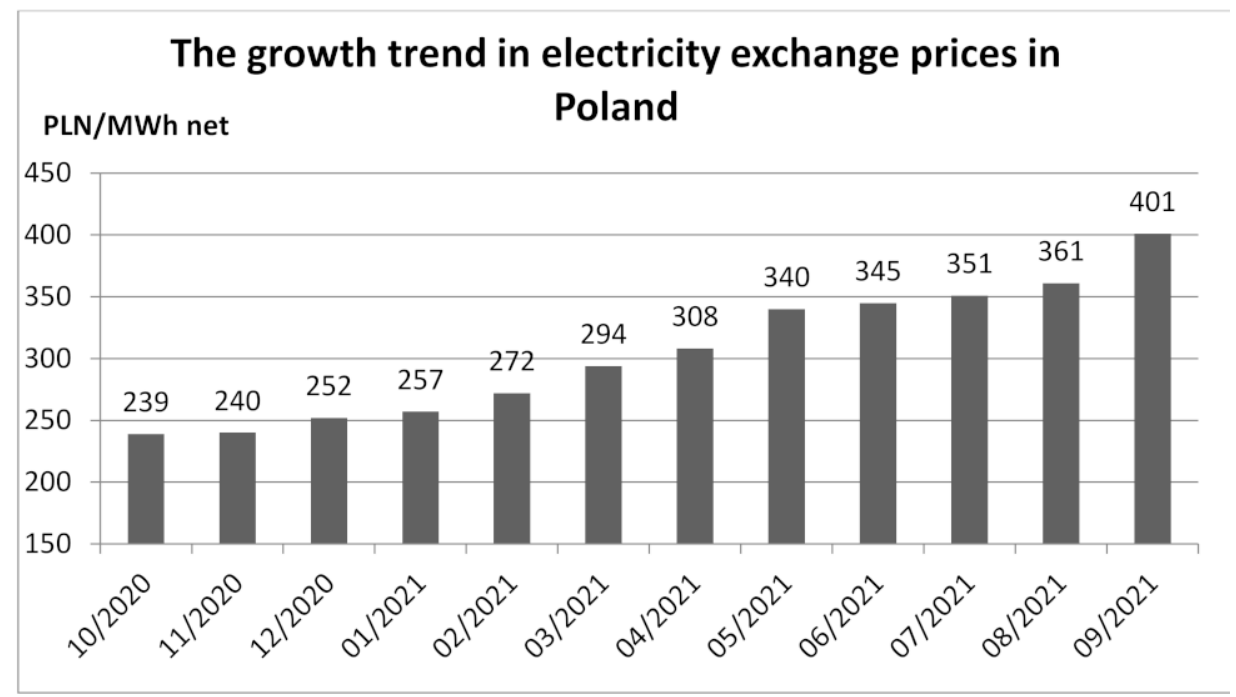

Figure 3. The growth trend in electricity exchange prices in Poland is October 2020-September 2021 [45].

Wholesale electricity prices on the European Union market have also been increasing. An analysis of the trend in wholesale prices in the European energy market is presented in Figure 4.

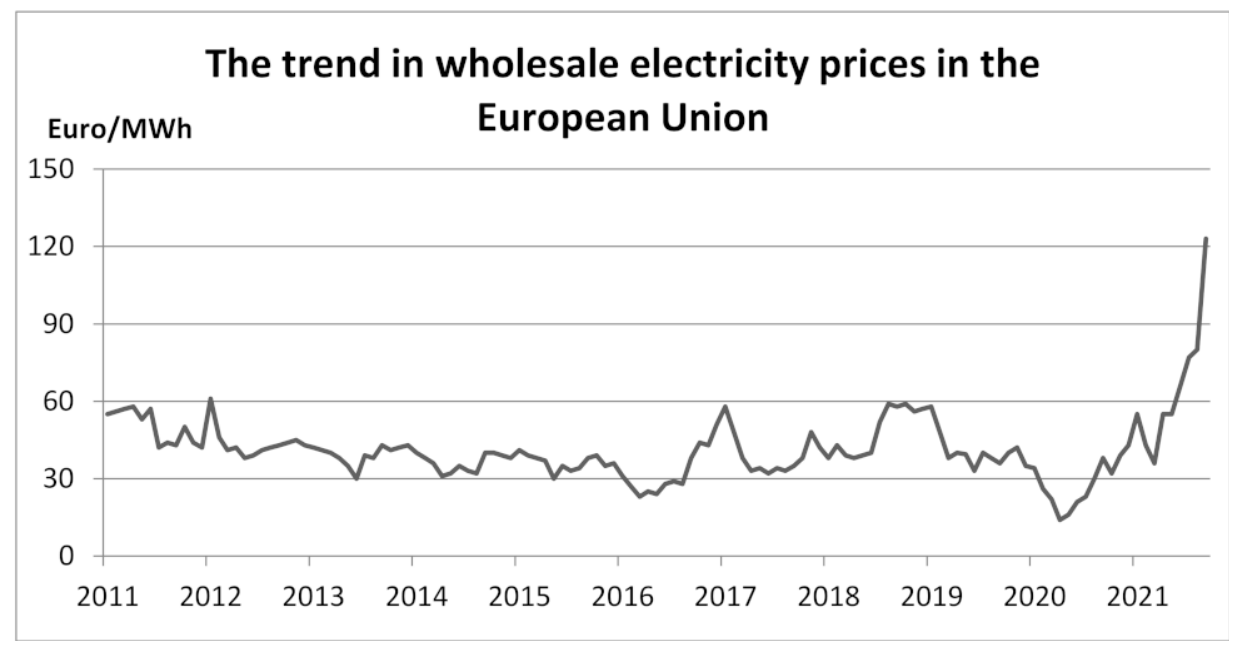

Figure 4. The trend in electricity exchange prices in the European Union from January 2011 to September 2021. [46].

The observed price increase trend means a real increase in electricity prices for the household sector in Poland and the Baltic States, which in Q1 this year amounted to: in Poland: 26.34, in Lithuania: 19.42, in Latvia: 19.46, in Estonia: 16.64 PPS per $100 \mathrm{KW.}$ 
An analysis of the trend in electricity prices in Poland does not give cause for optimism regarding the forecast of future purchase costs for electricity, which is produced mainly based on the classic generation model. There are over $50 \%$ share in the structure of electricity production in Poland is correlated with the cost of purchasing more expensive energy resources and $\mathrm{CO}_{2}$ emission allowances, which is currently over EUR 2.1 billion [43]. The need to seek alternatives to conventional sources of electricity generation is undeniable. A solid opening to green energy and the reconstruction of generation infrastructure, associated with investments of significant value, is essential. In this regard, photovoltaic solutions are attractive-recommended under the technical criterion in the subject of a wide range of applications and for legal, economic, and safety reasons [47,48].

\subsection{Analysis of the Photovoltaic Market in Poland and the Baltic States}

The photovoltaic market is developing rapidly in Poland and the Baltic States. The above is determined by current eco-trends, which are referred to in the energy policies of European and world economies, which aim to increase energy independence while reducing harmful environmental impacts $\left(\mathrm{CO}_{2}\right.$ emissions, groundwater declines, and permanent destruction of ecosystems). Undoubtedly, the generation of electricity from solar radiation is becoming an increasingly popular response to the challenge outlined above, so the promotion and support of solar energy generation facilities nowadays are necessary and justified.

The popularity of photovoltaics in the energy market in Poland is growing. Its value in 2020 in Poland exceeded the level of PLN 10 billion and is constantly growing, whereaccording to the estimates of Distribution System Operators-the first half of 2021 resulted in 144 thousand micro-installations being built, giving an increase in the power of the total solutions of this type by $1.65 \mathrm{GW}$ [43]. The total capacity of PV installations in Poland currently exceeds $6 \mathrm{GW}$ (up to $50 \mathrm{KW}$ ), with an approximately $40 \%$ share in RES and a $3.17 \%$ [49,50] share in Poland's total volume of electricity. Especially popular in Poland are micro-installations up to $10 \mathrm{kWp}$ [51]. The sinuous growth of photovoltaics in Poland (from 1.3 GW in 2019 to the planned $7 \mathrm{GW}$ in 2021) has been driven by a set of government subsidies, such as:

- instruments dedicated to individuals, such as "My electricity" [52], "Clean air", "Thermomodernisation allowance".

- instruments dedicated to economic operators, such as: "Energy Plus",

- instruments dedicated to farms, such as "Agroenergy", the agricultural tax deduction for photovoltaic investments.

It is projected that the photovoltaic market in Poland will continue to grow, although the unfavorable terrain in Poland is indicated in the literature [53,54], with annual insolation of $1000 \mathrm{kWh} / \mathrm{m}^{2}$ [17,55]. Therefore, especially intensive development is assumed in the segment of photovoltaic farms, which is expected to contribute to doubling the capacity of photovoltaic installations in Poland in 2024 [56]. Furthermore, promoting photovoltaic farm development programs above $1 \mathrm{MW}$ contributes to their development $[57,58]$, and energy production for companies' own needs is becoming increasingly popular in Poland [59].

The photovoltaic market in the Baltic States has not been prevalent, giving way to wind farms, especially offshore, which are strongly developing in the renewable energy sphere. However, Lithuania and Estonia's photovoltaic market development trend is beginning to gain momentum. On the other hand, Latvia is focusing its efforts on the development of alternative solutions (hydroelectric plants, wind farms). Details of the PV market in the individual Baltic States are as follows [60,61]:

\section{(a) Lithuania:}

The development of photovoltaic installations in Lithuania is of great interest to the public. The structure of solar energy installations in the country is based mainly on small installations with limited capacity, installed in the household sector. However, these installations are very numerous, and the energy obtained in this way already in 2019 assumed the level of $2.3 \%$ of the total volume of electricity production in Lithuania. In 
addition to small installations, Lithuania also invests in photovoltaic farms. Particularly popular are solutions to supply individual households with energy from the sun, the shares of which can be acquired by any Lithuanian, creating the dimension of "virtual prosumers". Buyers of shares corresponding to the acquisition of 2-3 KW will receive an adjustment to their electricity bills for participating in the program. The energy efficiency of such farms depends on their capacity, where, for example, for a $1 \mathrm{MW}$ solution, it is about $25 \mathrm{GWh}$ in 25 years.

Government instruments motivating the challenges of investing in photovoltaics are mainly financial. The targets for expanding photovoltaic capacity were reviewed this year, with 1 GW of photovoltaic capacity to be installed by 2025.

\section{(b) Latvia:}

Photovoltaics are not popular in Latvia. Of all the forms of renewable energy available, photovoltaics assume the least importance, and its share in the total volume of electricity production is about $0.1 \%$. This situation is due to the strong development of hydroelectricity, producing about $33 \%$ of the energy produced. The lack of interest in investing in photovoltaics is due to existing formal and legal barriers and the lack of government incentives to support the activities in question. Interestingly, Latvian entities invest in PV in Lithuania and Estonia, taking advantage of support solutions in neighboring countries.

(c) Estonia:

The development of photovoltaic installations in Estonia has undergone intensive development over the past few years. It started to develop particularly strongly in 2017-2018, with an intensive increase in PV installation capacity from $11 \mathrm{MW}$, through $50 \mathrm{MW}$ to $110 \mathrm{MW}$. As a result, in 2019, Estonia developed a $0.7 \%$ share of solar energy in the total volume of electricity produced, ranking 8th among EU member states with the highest per capita production of PV electricity. This action developed the target of res market development, which was assumed for 2030. The spectacular success of developing the photovoltaic market in Estonia is due to the instruments developed to support initiatives aimed at obtaining electricity based on PV solutions. These instruments included fast and transparent procedures for integrating PV installations into the grid, low equipment prices, a system of installation subsidies or financial bonuses for selling electricity to the grid. As a result, in addition to small and medium-sized installations, Estonia has begun to invest in industrial solutions in this field, including the construction of solar farms and parks.

The distribution of the share of photovoltaics in total electricity production in Poland and the Baltic States is visualized in Figure 5.

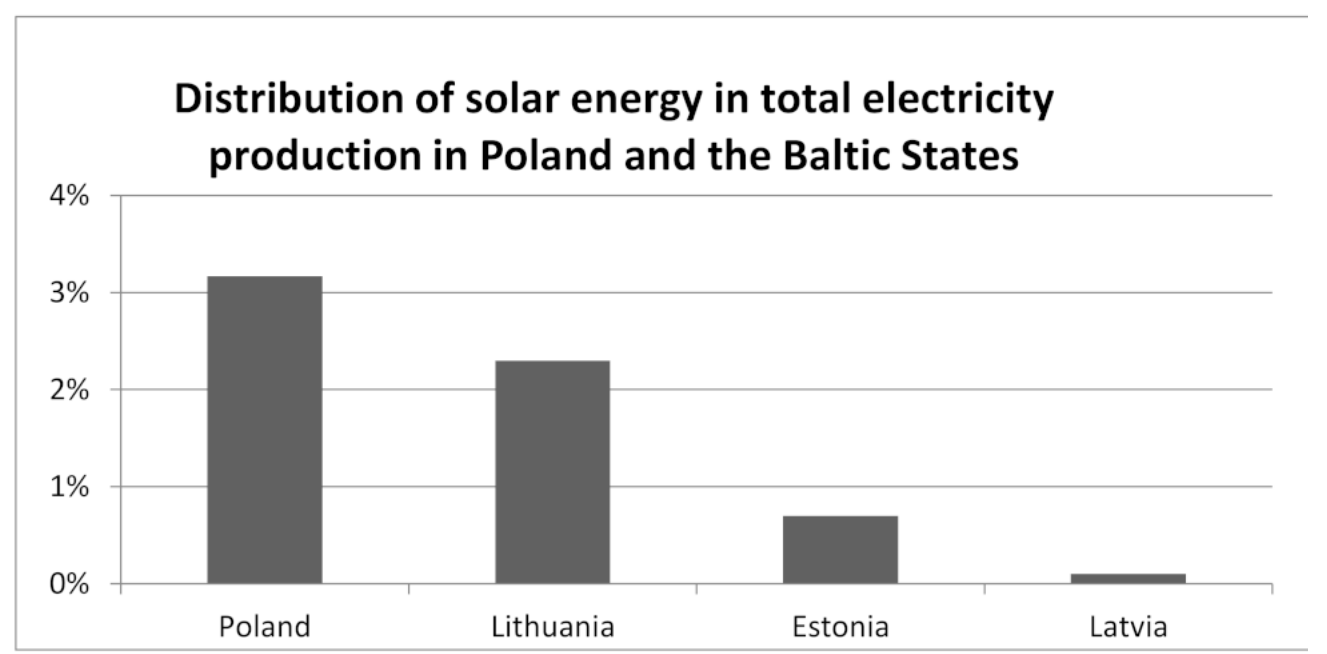

Figure 5. Distribution of the share of solar energy in the total volume of electricity production in Poland and the Baltic States $[60,61]$. 
In the examined set of countries, Poland takes the leading position with the share of $3.17 \%$ of energy from the sun in the country's total volume of electricity production. The lowest value of the share of photovoltaics in the total energy production at the economic level is generated by Latvia with a share of $0.1 \%$ of the total volume of electricity production in the country.

\subsection{Photovoltaics as an Alternative Energy Source-Analysis of Market Development Trends}

Photovoltaic installations contribute to reducing energy costs, so individual consumers decide to invest in green energy. However, choosing the right solution is not a simple matter. Additionally, one should remember about the right choice of power capacity because the overproduction of electricity in Poland is not economically justified [62,63].

The results of our own research "Bidding Effectiveness-Photovoltaics" (August 2021) indicate that the outlined, elementary knowledge of the photovoltaic process is critical for selecting the optimal, solutions available on the market. Analysis of the offering process (analysis of the range of offers, the level of acceptance of offers, the level of offer changes and their direction, as well as comments and opinions of the customer at the stage of offering and after-sales service), deepened with an interview with customer advisors, in a company with a significant market share in the distribution, installation, and servicing of photovoltaic installations in Poland (number of installations installed in 2020: 914), revealed that:

- Customers have relatively limited knowledge of the criteria for selecting the right ok for their energy needs, and around $80 \%$ fully accept the (technical) offer proposed by the vendor. The negotiation field is usually the price of the project.

- Purchase decisions are mainly determined (about $90 \%$ ) by the price of the installation, the lifetime of photovoltaic panels (about 85\%), the availability of solutions determining the time of investment implementation (about $70 \%$ ), and the aesthetics of the panels (about $45 \%$ ).

These studies have also revealed problems with clarifying technical uncertainties in the areas of:

- mono or polycrystalline installations-highlighting the differences in operating parameters creating the efficiency of the installation and their correlation with price,

- double-sided solutions (Bi-facial panels, drawing on bottom reflection),

- vision panels, excluding aspects of size, weight, and price.

This limits customer choice, reducing it significantly to the current (real) availability of specific assortments on the market and their price. Mass import of the most popular solutions (popularity determined by the promotion of solutions and their availability ensured by distribution points) translates into the observed mass sales in specific configurations and prices. The right choice elements of photovoltaic mounting are important in solution effectiveness and return on investment [64].

The relatively popular knowledge that the annual consumption of micro installations is in the range of $25-30 \%$ of energy paints a picture of the consumption potential of a microgrid that can include and supply energy to neighboring buildings. Interest in such a solution manifests itself in relations between buyers of photovoltaic installations and their suppliers. This topic was mentioned by approximately $20 \%$ of the customers purchasing photovoltaic installations in cooperation with the surveyed company. This shows the potential for market development, which is assumed to be more accessible for customers (financially and technically).

The analysis of the photovoltaic sector in Poland and the Baltic countries revealed the solution of "virtual prosumers", successfully practiced in Lithuania. The above inspired the authors of this paper to explore the potential for its application in Polish conditions. An interview conducted with the management of several dozen housing communities and several housing cooperatives confirms their clear interest in such a solution. The search for alternative solutions in the light of currently observed very serious increases in electricity 
prices strongly justifies the noted position. Participation in the photovoltaic farm with an average value of $3 \mathrm{KW}$ would significantly reduce the cost of electricity purchased by households. Residents of blocks of flats would be able to enjoy the benefits of green energy more extensively than the commonly offered energy mix tariff [65] where, according to the Polish Energy Policy, a consumer of electricity who does not have photovoltaic installation benefits from a variable daily mix of energy sources, including (residually) from RES. The above may inspire the development of serious investments in Poland. Entering into participation means opening the source of investment financing, at least in part. However, what is important is the system of incentives resulting from the formal and legal framework, which determines the directions and pace of development of the RES market in Poland and other countries.

\subsection{Coronavirus Pandemic and Photovoltaic Development on the Polish Market in the Baltic States}

The bulk of PV panel production is carried out in the Asian market, particularly in China. This is mainly due to the key mining sites for the abovementioned raw material, silicon (P-type and N-type silicon for the construction of P-N junctions), which is critical for the most frequent use in the production of PV panel joints. However, in principle, the alternative location does not limit the need to source from the Chinese raw material, which essentially polarizes the market concerned and increases the risk of liquidity of supply from one area.

The outbreak of the coronavirus pandemic and paralysis of supplies from the Chinese market [66] had a significant impact on the photovoltaic market in Poland and the Baltic States. Furthermore, the closure of seaports and airports contributed to a lack of panels [67], which resulted in the need to postpone planned and slow down or stop ongoing investments in the construction of solar farm installations of various scales. In addition, the process of acquiring new customers was almost abandoned. The negative effects of the above situation have been reinforced in Poland by the aspect of approximately $70 \%$ dependence of the Polish market on producers from Central Countries and the limited level of diversification of the system of suppliers from outside this region.

However, the lack of market capacity did not stop Chinese production, which, once the logistic channels were opened, resulted in full availability of PV solutions and a return to a free market, almost as soon as international trade was unfrozen. Furthermore, production "on stock" contributed to maintaining prices of PV installations at essentially pre-pandemic levels, which in turn resulted in a significant increase in interest in PV solutions in the Polish and Baltic markets.

The collapse in the stability of the foreign exchange market, caused by the global crisis of pandemic-weakened economies, contributed to a significant increase in the prices of photovoltaic installation components, i.e., photovoltaic modules, inverters, inverters, etc., due to the increase in their production and acquisition costs. A noticeable increase in prices in this area has been observed since September 2021, with a significant deepening of the recorded trend occurring in November. The above is particularly reflected in the Polish market due to the highest level of depreciation of the Polish currency in many years. Lithuania, Latvia, and Estonia, which use the European currency, have not experienced such changes.

The change of the Polish currency's average exchange rate against the Baltic states' currencies is presented in Figure 6. 


\section{Average exchange rate of the Polish currency in relation to the currency of the Baltic countries (Euro)}

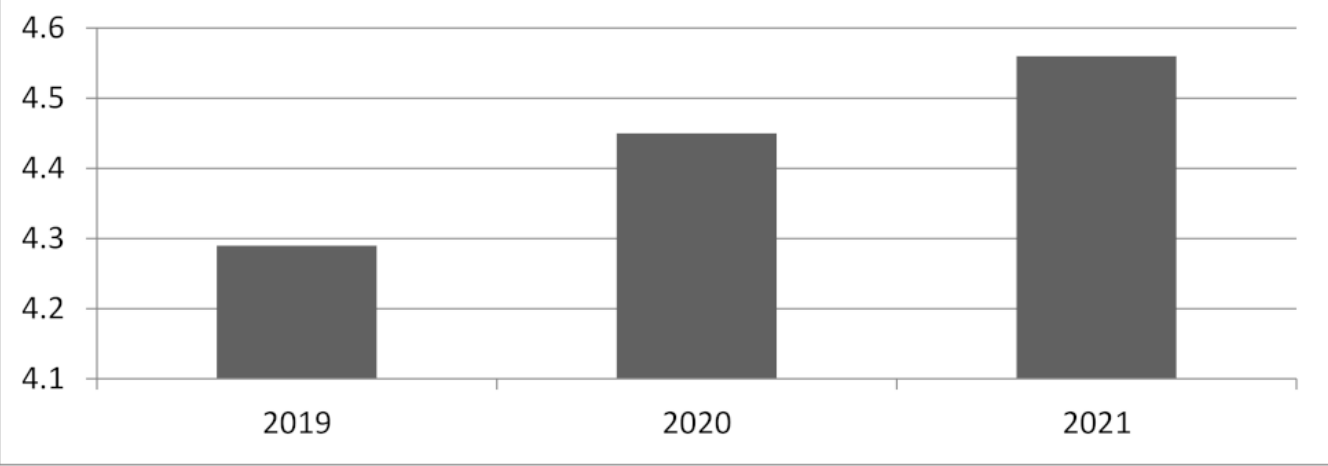

Figure 6. The change average exchange rate of the Polish currency (PLN) against the currency of the Baltic countries (Euro) in the period 1 December 2019-1 September 2021 [68].

Despite appearances, the photovoltaic market is not slowing down. On the contrary, in Poland, the opposite trend is observed. The above interest is strengthened by the announced change in legislation, according to which prosumers (producers and consumers of electricity at the same time) will be subject to different, less favorable than the current settlement rules in the mode of sale of overproduction of electricity and its "return" purchase to balance the needs $[69,70]$.

It is difficult to estimate the strength of the photovoltaic market development in Polan once the announced regulations come into force. It is also difficult to assess the intensity of its development in the coming years in the Baltic countries. However, the demand for green energy is expected to grow [71]. The main arguments support this, i.e., the environmentallyoriented action combined with care for the community's health, juxtaposed with an equally strong economic argument-energy obtained from renewable sources is relatively cheap.

An analysis of the opinions of users of photovoltaic installations in Poland (obtained in the course of the research "Effectiveness of the offer-photovoltaics", referred to in this paper, August 2021), reveals that out of ten potential customers initially interested in photovoltaics, on average six decide to take up the challenge of purchasing photovoltaic solutions. On average, two more declare their interest in taking up such a solution in the future. Notably, four out of six customers benefiting from solutions based on this energy generation and conversion model indicate their satisfaction with the acquisition of electricity. At the same time, the remainder needs a longer perspective to assess the effects. According to the analysis of average electricity consumption loads with photovoltaic solutions, the potential for bill reduction can be generally estimated to be around $70 \%$ of their value, sometimes even $80-90 \%$ [71]. Such a range is indicated by at least half of the surveyed customers (i.e., min. 457) of the company referred to in this study, in a service interview conducted after a year of using the installation. The above research, although conducted on the Polish market, confirms the common knowledge that the key argument for electricity consumers is the price of its acquisition.

\section{Discussion}

The results of the considerations in this article confirm that the development of photovoltaics in Poland and the Baltic countries are the right direction to strengthen the acquisition of energy from renewable sources. However, this direction is determined by the energy policy of individual economies, which is translated into a system of regulations and incentives, directing investors to take up the challenge of building photovoltaic installations with a certain force. The above is confirmed by the policy of Poland, Estonia, and also Lithuania developing in this area. The system of incentives may be used by foreign 
investors, as it is noted in Lithuania and Estonia, where investments are made by entities from neighboring Latvia, stimulating the economic development of these economies. The lack of government support does not motivate investment activities in this area (Latvia). This confirms the importance of support instruments in the development of RES. However, it should be remembered that there are EU support programs for the development of the green energy market, with particular emphasis on the photovoltaic market. This form of support is used by numerous entities oriented towards developing photovoltaics.

The main participants in the photovoltaic segment of the energy markets in Poland and the Baltic States are small prosumers (owners of micro photovoltaic installations below $50 \mathrm{KW}$-producing and consuming their energy). The impulse for small investors to reach for photovoltaic solutions is, in principle, the aspect of optimizing the economic bill for electricity consumption, but in Poland, decisions in the field of photovoltaic solutions are made mainly based on suggestions from retailers. Therefore, the diagnosed state of the photovoltaic sector in Poland and the Baltic countries reveals potential for further development of the observed trends. At the same time, there is a wide perspective for the development of the photovoltaic market in the commercial dimension, which is very likely to happen soon.

The main conclusion is to confirm the economic rationale for further development of the photovoltaic sector in Poland and the Baltic countries. The justification arises against the background of energy policy, correlated with the conditions of sustainable development of individual economies and the costs of achieving the resulting objectives. Economic justification, however, should be found most strongly by the investor who undertakes the construction of photovoltaic installations, hence it is extremely important to maintain the system of incentives and intense promotion of this direction of energy acquisition. The announced unfavorable regulations in accounting for the surplus of produced energy and purchasing its shortage already this year may significantly limit this strongly developing renewable energy market in Poland.

Moreover, the "virtual prosumers" model may serve as an inspiration for strengthening the energy market development in Poland. This is an interesting direction of development of major investments, enabling the general public to take advantage of the benefits of green energy, the interest triggered mainly by the financial aspect, as well as social responsibility, in connection with strongly marked widespread environmental protection activities.

Pandemic conditions in 2020 only temporarily slowed down the development of the PV market in Poland and the Baltic States. With the opening of international exchanges, the stream of orders and installations of photovoltaic solutions has significantly increased in the area under analysis. The greatest risk of a pandemic, however, is a general weakening of economies, currency market fluctuations, and the currently observed increase in the prices of energy raw materials, determining the marked pan-European increase in wholesale electricity prices, to a significant extent still generated by conventional means (e.g., Poland). In this light, the development of RES assumes particular importance. However, the price increase also applies to components for the production of photovoltaic system accessories. This will probably not stop the observed development of the photovoltaic market in Poland and the Baltic States, but it may weaken its intensity. The above draws an interesting spectrum of further possible research.

Author Contributions: All authors have made significant contributions to this paper from the conception of the study through the identification and selection of the research methodology and its conduct, the writing of the paper, and its editorial side. All authors have read and agreed to the published version of the manuscript.

Funding: This research received no external funding.

Informed Consent Statement: Informed consent was obtained from all subjects involved in the study.

Data Availability Statement: Not applicable. 
Acknowledgments: Not applicable.

Conflicts of Interest: The authors declare no conflict of interest.

\section{References}

1. Magor, R. Odnawialne źródła energii w gospodarce litewskiej, Polityka Energetyczna. Energy Policy J. 2017, $20,140$.

2. Yang, L.; Wang, X.-C.; Dai, M.; Chen, B.; Qiao, Y.; Deng, H.; Zhang, D.; Zhang, Y.; Almeida, C.; Chou, A.; et al. Shifting from Fossil-Based Economy to Bio-Based Economy: Status Quo, Challenges, and Prospects. Energy 2021, 228, 120533. [CrossRef]

3. IRENA. Renewable Power Generation Costs in 2019; IRENA: Abu Dhabi, United Arab Emirates, 2020.

4. Golarz, M. Bezpieczeństwo energetyczne Polski na przykładzie zaopatrzenia w gaz ziemny, ropę naftową i energię elektryczną. Bezpieczeństwo. Teor. I Prakt. 2016, 22, 161-180.

5. Łukasiewicza, I. Bezpieczeństwo Energetyczne Polski I Europy-Uwarunkowania-Wyzwania-Innowacje, Instytut Polityki Energetycznej Im; Ruszel, M., Podmiotko, S., Eds.; Instytut Polityki Energetycznej: Rzeszów, Poland, 2019; pp. 5-8.

6. Sustainable Development Report 2019. Transformations to Achieve the Sustainable Development Goals. Available online: https://s3.amazonaws.com/sustainabledevelopment.report/2019/2019_sustainable_development_report.pdf (accessed on 5 January 2021).

7. Amri, F. Intercourse across Economic Growth, Trade and Renewable Energy Consumption in Developing and Developed Countries. Renew. Sustain. Energy Rev. 2017, 69, 527-534. [CrossRef]

8. Ben Jebli, M.; Ben Youssef, S. The Environmental Kuznets Curve, Economic Growth, Renewable and Non-Renewable Energy, and Trade in Tunisia. Renew. Sustain. Energy Rev. 2015, 47, 173-185. [CrossRef]

9. Menegaki, A.; Tiwari, A. The Index of Sustainable Economic Welfare in the Energy-Growth Nexus for American Countries. Ecol. Indic. 2017, 72, 494-509. [CrossRef]

10. Menegaki, A.N.; Tugcu, C.T. Energy Consumption and Sustainable Economic Welfare in G7 Countries; A Comparison with the Conventional Nexus. Renew. Sustain. Energy Rev. 2017, 69, 892-901. [CrossRef]

11. Slusarczyk, B.; 'Zegle 'n, P.; Kluczek, A.; Nizioł, A.; Górka, M. The Impact of Renewable Energy Sources on the Economic Growth of Poland and Sweden Considering COVID-19 Times. Energies 2022, 15, 332. [CrossRef]

12. Quitzow, R.; Bersalli, G.; Eicke, L.; Jahn, J.; Lilliestam, J.; Lira, F.; Marian, A.; Süsser, D.; Thapar, S.; Weko, S.; et al. The COVID-19 Crisis Deepens the Gulf between Leaders and Laggards in the Global Energy Transition. Energy Res. Soc. Sci. 2021, 74, 101981. [CrossRef]

13. From January, We Will Pay PLN 21 More for Electricity. Available online: https://www.ure.gov.pl/pl/urzad/informacje-ogolne/ aktualnosci/9963,Od-stycznia-za-prad-zaplacimy-o-21-zl-wiecej.html (accessed on 5 January 2021).

14. Rising Energy Prices Can Have Dire Consequences-Social Unrest Threatens. Available online: https://businessinsider. com.pl/finanse/finansisci-wzrost-cen-energii-moze-miec-fatalne-skutki-groza-niepokoje-spoleczne/2hdsx0h (accessed on 5 January 2021).

15. Salim, R.A.; Rafiq, S. Why Do Some Emerging Economies Proactively Accelerate the Adoption of Renewable Energy? Energy Econ. 2012, 34, 1051-1057. [CrossRef]

16. Omri, A.; Daly, S.; Nguyen, D.K. A Robust Analysis of the Relationship between Renewable Energy Consumption and Its Main Drivers. Appl. Econ. 2015, 47, 2913-2923. [CrossRef]

17. Pestana, D.G.; Rodrigues, S.; Morgado-Dias, F. Environmental and economic analysis of solar systems in Madeira, Portugal. Util. Policy 2018, 55, 31-40. [CrossRef]

18. Peng, J.; Lu, L.; Yang, H. Review on life cycle assessment of energy payback and greenhouse gas emission of solar photovoltaic systems. Renew. Sustain. Energy Rev. 2013, 19, 255-274. [CrossRef]

19. Bilgili, F.; Ozturk, I. Biomass Energy and Economic Growth Nexus in G7 Countries: Evidence from Dynamic Panel Data. Renew. Sustain. Energy Rev. 2015, 49, 132-138. [CrossRef]

20. National Centre for Emissions Management. CO2, SO2, NOx, CO and Total Dust Emission Ratios for Electricity Based on the Information Contained in the National Database of Greenhouse Gas Emissions and other Substances for 2018. Available online: https://www.kobize.pl/uploads/materialy/materialy_do_pobrania/wskazniki_emisyjnosci/Wskazniki_emisyjnosci_ grudzien_2019.pdf (accessed on 6 January 2022).

21. Sampaio, P.G.V.; González, M.O.A. Photovoltaic solar energy: Conceptual framework. Renew. Sustain. Energy Rev. 2017, 74, 590-601. [CrossRef]

22. Ministerstwo Gospodarki. Polityka Energetyczna Polski Do 2030 Roku; Ministerstwo Gospodarki: Warszawa, Poland, 2009.

23. Ministerstwo Energii. Polityka Energetyczna Polski Do 2040 Roku; Ministerstwo Energii: Warszawa, Poland, 2018.

24. Bhuiyan, M.A.; An, J.; Mikhaylov, A.; Moiseev, N.; Danish, M.S.S. Renewable Energy Deployment and COVID-19 Measures for Sustainable Development. Sustainability 2021, 13, 4418. [CrossRef]

25. Eroğlu, H. Effects of COVID-19 Outbreak on Environment and Renewable Energy Sector. Environ. Dev. Sustain. 2021, 23, 4782-4790. [CrossRef]

26. Available online: https://vosti.pl/aktualnosci/efekt-fotowoltaiczny-definicja-zasada-dzialania/ (accessed on 27 November 2021).

27. Frydrychowicz-Jastrzebska, G.; Bugała, A. Solar Tracking System with New Hybrid Control in Energy Production Optimization from Photovoltaic Conversion for Polish Climatic Conditions. Energies 2021, 14, 2938. [CrossRef] 
28. Dobrzycki, A.; Kurz, D.; Maćkowiak, E. Influence of Selected Working Conditions on Electricity Generation in Bifacial Photovoltaic Modules in Polish Climatic Conditions. Energies 2021, 14, 4964. [CrossRef]

29. Micheli, D.; Alessandrini, S.; Radu, R.; Casula, I. Analysis of the outdoor performance and efficiency of two grid-connected photovoltaic systems in northern Italy. Energy Convers. Manag. 2014, 80, 436-445. [CrossRef]

30. Phinikarides, A.; Makrides, G.; Zinsser, B.; Schubert, M.; Georghiou, G.E. Analysis of photovoltaic system performance time series: Seasonality and performance loss. Renew. Energy 2015, 77, 51-63. [CrossRef]

31. The Largest PV Markets in the World in 2020. Available online: https://www.gramwzielone.pl/energia-sloneczna/105931 /najwieksze-rynki-pv-na-swiecie-w-2020-chiny-usa-i-zaskoczenie (accessed on 5 January 2021).

32. Photovoltaics 2020 and Statistics. Available online: https://stiloenergy.pl/fotowoltaika-a-statystyki-czyli-garsc-danycho-panelachfotowoltaicznych/?gclid=Cj0KCQiAw9qOBhC-ARIsAGrdn533_3Ch3CpyQ7o6Si7las5v-3xkzUnMgbyjznlSQD0 RPTahGg66KsaArUAEALw_wcB (accessed on 5 January 2021).

33. Olczak, P.; Olek, M.; Matuszewska, D.; Dyczko, A.; Mania, T. Monofacial and Bifacial Micro PV Installation as Element of Energy Transition-The Case of Poland. Energies 2021, 14, 499. [CrossRef]

34. Jäger-Waldau, A.; Kougias, I.; Taylor, N.; Thiel, C. How photovoltaics can contribute to GHG emission reductions of $55 \%$ in the EU by 2030. Renew. Sustain. Energy Rev. 2020, 126, 109836. [CrossRef]

35. Jaeger-Waldau, A. PV Status Report 2019; Publications Office of the European Union: Brussels, Belgium, 2019.

36. European Commission. A Clean Planet for All. A European Long-Term Strategic Vision for a Prosperous, Modern, Competitive and Climate Neutral Economy; EUR-Lex: Brussels, Belgium, 2018.

37. We Already Have 2 GW in Photovoltaics, but in Europe, We Are Still in the Second Ten. Available online: https: / / www.gramwzielone.pl/energia-sloneczna/103219/mamy-juz-2-gw-w-fotowoltaice-ale-w-europie-jestesmy-jeszczew-drugiej-dziesiatce (accessed on 6 January 2021).

38. Frankfort-Nachmias, C.; Nachmias, D. Research methods in social sciences; Zysk i S-ka Publishing House: Warsaw, Poland, 2001.

39. Edoo, N.; Ah King, R.T.F. Techno-Economic Analysis of Utility-Scale Solar Photovoltaic Plus Battery Power Plant. Energies 2021, 14, 8145. [CrossRef]

40. Available online: https:/ / ec.europa.eu/eurostat (accessed on 29 November 2021).

41. Own Elaboration. Available online: https://ec.europa.eu/eurostat/documents/4187653/11581527/Evolution+of+household+ electricity+and+gas+prices+in+the+EU.png/8e8a38f6-e791-ee36-c14c-844b91fad606?t=1634632173305 (accessed on 29 November 2021).

42. Available online: https://www.ure.gov.pl/pl/urzad/informacje-ogolne/aktualnosci/9964,Od-stycznia-ok-9-zlotych-wiecejna-rachunkach-kuchenkowiczow.html (accessed on 29 November 2021).

43. Electricity Prices Continue to Rise-How to Avoid Ever-Higher Bills? Available online: https://wysokienapiecie.pl/41708-cenypradu-nie-przestaja-rosnac-jak-uniknac-coraz-wyzszych-rachunkow (accessed on 29 November 2021).

44. Nord Pool, Energy live, September 2021. Available online: https://wysokienapiecie.pl (accessed on 29 November 2021).

45. Own Elaboration. Available online: https://wysokienapiecie.pl/wp-content/uploads/2021/10/TGE-Wykres-Sunday-Polska.jpg (accessed on 29 November 2021).

46. Own Elaboration. Available online: https://businessinsider.com.pl/gospodarka/podwyzki-cen-pradu-w-ue-oto-co-mozezrobic-komisja-europejska-na-rynku-energii-i-gazu/h8sw8wy (accessed on 29 November 2021).

47. Almeshaiei, E.; Al-Habaibeh, A.; Shakmak, B. Rapid evaluation of micro-scale photovoltaic solar energy systems using empirical methods combined with deep learning neural networks to support systems' manufacturers. J. Clean. Prod. 2020, 244, 118788. [CrossRef]

48. Bukowski, M.; Majewski, J.; Sobolewska, A. Macroeconomic Electric Energy Production Efficiency of Photovoltaic Panels in Single-Family Homes in Poland. Energies 2021, 14, 126. [CrossRef]

49. Installed Capacity of Photovoltaics in Poland. Available online: https://www.rynekelektryczny.pl/moc-zainstalowanafotowoltaiki-w-polsce (accessed on 20 November 2021).

50. The Power of Photovoltaic Power Plants in Poland Exceeded 6 GW. Available online: https://www.gramwzielone.pl/energiasloneczna/106509/moc-elektrowni-fotowoltaicznych-w-polsce-przekroczyla-6-gw (accessed on 29 November 2021).

51. Olczak, P.; Matuszewska, D.; Kryzia, D. "Mój Prąd" as an example of the photovoltaic one off grant program in Poland. Energy Policy J. 2020, 23, 123-138. [CrossRef]

52. Olczak, P.; Kryzia, D.; Matuszewska, D.; Kuta, M. “My Electricity” Program Effectiveness Supporting the Development of PV Installation in Poland. Energies 2021, 14, 231. [CrossRef]

53. Chalecka, K. Możliwości Wykorzystania Odnawialnych Zasobów Energetycznych W POLSCE; Acta Universitatis Nicolai Copernici: Toruń, Poland, 2010; pp. 136-137.

54. Ogarek, P. Przyszłość odnawialnych źródeł energii w Polsce w oparciu o Politykę Energetyczną Polski do 2040 roku. In Bezpieczeństwo Energetyczne Polski I Europy_Uwarunkowania-Wyzwania—Innowacje, Instytut Polityki Energetycznej im I. Łukaszewicza; Ruszel, M., Podmiotko, S., Eds.; Instytut Polityki Energetycznej: Rzeszów, Poland, 2019; p. 104.

55. Chwieduk, D.; Chwieduk, M. Determination of the Energy Performance of a Solar Low Energy House with Regard to Aspects of Energy Efficiency and Smartness of the House. Energies 2020, 13, 3232. [CrossRef]

56. Fotowoltaika-2021. Available online: https://enerad.pl/aktualnosci/fotowoltaika-2021/ (accessed on 28 November 2021).

57. Komorowska, A.; Kaminski, J. A review of the 2018 Polish capacity market auctions. Energy Policy J. 2019, 22, 75-88. [CrossRef] 
58. Paska, J.; Surma, T.; Terlikowski, P.; Zagrajek, K. Electricity generation from renewable energy sources in Poland as a part of commitment to the polish and EU energy policy. Energies 2020, 13, 4261. [CrossRef]

59. IEO. “ isn Market in Poland 2020; IEO: Warsaw, Poland, 2020.

60. Sun for everyone-Development of Photovoltaic Installations in the Baltic States. Available online: https://ies.lublin.pl/ komentarze/slonce-dla-wszystkich-rozwoj-instalacji-fotowoltaicznych-w-panstwach-baltyckich/ (accessed on 29 November 2021)

61. Lithuanians Introduced the Concept of a Virtual Prosumer. Available online: https://www.gramwzielone.pl/energia-sloneczna/ 102933/litwini-wprowadzili-koncepcje-wirtualnego-prosumenta (accessed on 20 November 2021).

62. Mirowski, T.; Sornek, K. Potential of prosumer power engineering in Poland by example of micro PV installation in private construction. Energy Policy J. 2015, 18, 73-84.

63. Pepłowska, M.; Olczak, P. The tilt angle selecting problem of PV panels taking the energy demand profile into account. Bull. Miner. Energy Econ. Res. Inst. Pol. Acad. Sci. 2018, 102, 91-100.

64. Bugała, D.; Bugała, A.; Machczynski, W. Simulation of the Immunity Test of a Photovoltaic System Disturbed by Electromagnetic Voltage Surge. Energies 2021, 14, 3646. [CrossRef]

65. Szczerbowski, R. Energy security of Poland-Energy mix and energy efficiency. Polityka Energetyczna 2013, 16, 35-47.

66. Coronawirus-COVID-19. Available online: https:// fotowoltaika.bruk-bet.pl/blog/nasz-wklad-w-rozwoj-branzy/koronawiruscovid19-gospodarka-rynek-fotowoltaiki/ (accessed on 29 November 2021).

67. Own Elaboration. Available online: https://www.nbp.pl/home.aspx?c=/ascx/archa.ascx (accessed on 29 November 2021).

68. Consequences of the Coronavirus Epidemic for the EU Economy. Available online: https://pism.pl/publikacje/Konsekwencje_ epidemii_koronawirusa_dla_gospodarki_UE (accessed on 6 January 2022).

69. What Awaits the Photovoltaic Industry in 2022? Available online: https://www.wnp.pl/energetyka/co-czeka-branzefotowoltaiczna-w-2022-roku,524318.html (accessed on 6 January 2022).

70. Changes in the Field of Photovoltaics from January 2022. Available online: https://fgenergy.pl/zmiany-przepisow-w-zakresiefotowoltaiki-od-stycznia-2022-roku-lepiej-sie-pospiesz/ (accessed on 29 November 2021).

71. High Electricity Bill with Photovoltaics, What Could be the Reason? Available online: https://enerad.pl/aktualnosci/wysokirachunek-za-prad-przy-fotowoltaice-co-moze-byc-przyczyna/ (accessed on 29 November 2021). 